\title{
Comparison of Overfeeding Influence on Slaughter Performance, Small Intestinal Physiology and Microbiota between Gang Goose and Tianfu Meat Goose
}

\author{
Rongxue Wei ${ }^{1}$, Fengjiang $\mathrm{Ye}^{1}$, Fang $\mathrm{He}^{1}$, Qi Song ${ }^{1}$, Xiangping Xiong ${ }^{1}$, Wenlan Yang ${ }^{1}$, Hongyong Xu ${ }^{1}$, Liang $\mathrm{Li}^{1}$, Hehe \\ $\mathrm{Liu}^{1}$, Xianyin Zeng ${ }^{2}$, Ling Chen ${ }^{3}$ and Chunchun $\mathrm{Han}^{1 *}$ \\ ${ }^{I}$ Farm Animal Genetic Resources Exploration and Innovation Key Laboratory of Sichuan Province, Sichuan Agricultural University, Chengdu, \\ Sichuan, 611130, P.R. China \\ ${ }^{2}$ College of life science, Sichuan Agricultural University, Ya'an, Sichuan, 625014, P.R. China \\ ${ }^{3}$ Xichang Huanong Poultry Co., Xichang, Sichuan, 615000, P.R. China \\ *Corresponding author’s Email: chunchunhai_510@163.com; ORCID: 0000-0002-8692-767X
}

Received: 20 Apr. 2020

Accepted: 01 June. 2020

\begin{abstract}
The objective of this research was to compare the influence of overfeeding on slaughter performance and small intestinal physiology and microbiota between Gang goose and Tianfu Meat Goose. Fifty Gang geese were randomly divided into the control group and overfed group, as were fifty Tianfu Meat geese. All geese were slaughtered after 3 weeks of overfeeding. After overeating, the results indicated that the liver weight, villus height to crypt depth ratio in duodenum and ileum, and the activity of invertase and maltase enzymes of Tianfu Meat goose was higher than those of Gang goose. However, the subcutaneous adipose tissue weight of Gang goose was higher than that of Tianfu Meat goose. Moreover, the Enterobacterial Repetitive Intergenic Consensus-Polymerase Chain Reaction (ERIC-PCR) fingerprint indicated that the band number of intestinal bacteria in each small intestinal segment decreased in Gang goose and increased in Tianfu Meat goose. The Enterobacter had a higher gene expression in the jejunum of Gang goose than that of Tianfu Meat goose and Escherichia coli the gene expression decreased in the ileum of Tianfu Meat goose after overfeeding. In conclusion, Tianfu Meat goose's liver weight, small intestinal digestion and absorption capacity and microbiota homeostasis were much better than those of Gang goose. Therefore, Tianfu Meat goose is more suitable for foie gras production. The results of the present study will provide a reference for the use of goose breeding for overfeeding and the relationship between intestinal physiology and the mechanism of goose fatty liver formation.
\end{abstract}

Key words: Digestive enzyme, Goose, Intestinal flora, Intestinal morphology, Overfeeding

\section{INTRODUCTION}

China has the largest number of geese in the world and has a number of indigenous and developed goose breeds. Goose breeding is the primary determinant for foie gras production. Researching the production performance of these breeds under overfeeding is essential for the use of these breeds for foie gras production. The small intestinal is the most important place where nutrients have been digested and absorbed. The growth of the animal relies on the digestion and absorption of the nutrients. Therefore, it is important to investigate the influence on small intestinal structure morphology, digestive enzymes activity and flora to improve the yield of foie gras through overfeeding.

Different goose breeds have a very different performance from foie gras. Landes Goose is the special breed for foie gras production and has the best foie gras performance (Geng et al., 2016). Some researchers reported that there is a negative effect on the digestion, absorption, and utilization of nutrients when the waterfowls were overfed (Zhang et al., 2007). Different duck genotypes have different intestinal microbiota compositions (Vasai et al., 2014). A study of Langdes Goose indicated that the prosperity and diversity of the bacterial communities in the ileum and cecum decreased after overfeeding (Tang et al., 2018). Liu et al. (2016) reported that Firmicutes in the duodenal, jejunum and ileum were more densely distributed than in caeca, and their abundance was affected by overfeeding, in overfed geese.

At the present experiment, an influence of overfeeding on the morphology of the intestine structure, 
and the activity of digestive enzyme has rarely been reported in geese. Flora researches mainly focused on Landes goose and there have been few reports of other goose breeds. Gang goose is an excellent indigenous goose breed distributing in southwest China. It is characterized by large body size, fast growth rate and strong fat storage capacity. Tianfu Meat goose is a developed goose breed from the Sichuan Agricultural University with many outstanding achievements, for example, excellent egglaying, fast growth rate and strong adaptability. In the present study, a comparison was performed of the influence of overfeeding on slaughter performance, the morphology of the small intestine structure, digestive enzymes activity and the flora between Gang goose and Tianfu Meat goose. The present study will provide a reference for the development and use of breed resources for foie gras production and provide a foundation for further investigation of intestinal health and the mechanism of goose fatty liver formation.

\section{MATERIALS AND METHODS}

\section{Ethical Approval}

All authors in the present study had to be approved by the Institutional Animal Care and Use Committee (IACUC) of Sichuan Agricultural University (Permit No. DKY-B20141401), and carried out in accordance with the approved guidelines. All efforts were made to minimize the animals suffering. The movement of birds was not restricted until the age of 90 days.

\section{Birds, Experiment design and sampling}

Fifty newborn male Tianfu Meat geese and fifty newborn male Gang geese were raised. At the age of 13 weeks, the geese of each breed were randomly divided into two groups, each containing a control group from Gang goose and an overfed group from Gang goose, the control group from Tianfu Meat goose and an overfed group from Tianfu Meat goose, each group comprising 25 geese. The control group geese were fed as before; the geese of the overfed group were overfed with boiled maize (5 minutes boiled maize, supplemented with $1 \%$ vegetable oil and $1 \%$ salt), the daily feed intake reached 600-750 gram (g) (4 meals per day) and given free access to water. The temperature and the relative humidity of the room were maintained at $24^{\circ}$ centigrade $\left({ }^{\circ} \mathrm{C}\right.$.), and 65 to $70 \%$, respectively, until the end of the experiment. Geese and overfeeding places were provided by Xichang Huanong Poultry Compony, Sichuan, China. All geese were slaughtered of age if overfeeding. After 12 hours of fasting, the geese were killed. The geese were weighed before slaughter; the geese slaughter weight was weighed after slaughter. The samples of abdominal fat, subcutaneous adipose tissue and liver were collected and weighed immediately. The weight and length of each section of the intestine were measured and weighted after slaughtering and dividing. Five geese in each group were anesthetized with an intraperitoneal injection of sodium pentobarbital (60 milligram per kilogram $(\mathrm{mg} / \mathrm{kg})$ ), and then immediately sacrificed for small intestinal tissue and content. Small intestinal tissue was washed in ice-cold saline $\left(0.9 \% \mathrm{NaCl} ; 4{ }^{\circ} \mathrm{C}\right)$ and fixed in $4 \%$ formaldehydephosphate buffer to determine intestinal morphological, and the small intestinal contents were frozen in liquid nitrogen and then kept at $-80{ }^{\circ} \mathrm{C}$ for digestive enzyme activity, Enterobacterial Repetitive Intergenic ConsensusPolymerase Chain Reaction (ERIC-PCR) and quantitative fluorescence Polymerase Chain Reaction (PCR) of the intestinal flora assay.

\section{Small intestine morphological examinations}

According to the methods of Cao et al. (2015), the cross-sections from the middle of the duodenum, jejunum, and ileum were preserved in $4 \%$ formaldehyde-phosphate buffer were prepared using standard paraffin embedding techniques, sectioned $(5 \mu \mathrm{m})$ and stained with Hematoxylin and Eosin (HE), and then sealed by neutral resin size, and then examined by microscope photography system (Olympus, Tokyo, Japan). Each slice was observed and 5 visual fields were randomly scanned. Visual measurements of villus height, crypt depth, and intestinal wall thickness were measured 10 times and measured in each field of view with $40 \times$ magnification using imaging software (Image Pro Plus 6.0, Media Cybernetics, Bethesda, MD, USA)

\section{Small intestine digestive enzymes activity examinations}

According to the previous research (Cao et al., 2018), approximately $0.1 \mathrm{~g}$ of frozen small intestinal contents were accurately weighed, and placed in sterile Eppendorf tubes containing 9 volumes (weight / volume) of ice-cold normal saline ( 0.7 gram / milliliter). The mixture of small intestinal contents and normal saline was centrifuged at 4000 revolution / minute for 15 minutes at $4^{\circ} \mathrm{C}$. The supernatant was then obtained and kept at $-20^{\circ} \mathrm{C}$, which was used for the study of the enzyme activity. The protein concentration of the samples was employed to calculate digestive activities, and assayed using a protein quantification kit (Bicinchoninic Acid 
Assay, Beyotime Biotechnology, Beijing, China); the kits, which assayed the activity of amylase, maltase, invertase, chymotrypsin were provided by the Nanjing Jiancheng Bioengineering Institute (Nanjing, China). All operations were carried out according to the instructons.

\section{Extraction of total DNA of small intestinal bacteria}

The fecal DNA extraction kit (DP328, Tiangen, Beijing, China) was used to extract bacterial genomic DNA from small intestinal contents; then the concentration of the extracted DNA was determined with an ultraviolet spectrophotometer (Nano Drop 2000, Thermo, USA). The purity and quality of the entire DNA was assessed by spectrophotometric absorption at 260/280 nanometer (nm) and the integrity of DNA was detected by agarose gel electrophoresis and the results were observed and photographed in the gel imaging system (Bio-Rad, USA).

\section{Detection and analysis of intestinal flora by ERIC-PCR}

The ERIC-PCR assay was performed according to the method described by Staji et al. (2018). The total DNA extracted from small intestinal bacteria was used to perform ERIC-PCR amplification using primers (ERIC-1: 5'-ATGTAAGCTCCTGGGGATTCAA-3'; ERIC-2: 5'AAGTAAGTGACTGGGGTGAGCG-3') (BGI, Beijing, China) (Wang et al., 2014). Amplification reactions were performed in a volume of 25 microliter $(\mu \mathrm{L})$ containing $1.5 \mu \mathrm{L}$ of each primer ( 25 picomole), $2 \mu \mathrm{L}$ of 2.5 millimole $(\mathrm{mM}) \mathrm{dNTPs}, 2.5 \mu \mathrm{L}$ of $10 \times$ Buffer, $2 \mu \mathrm{L}$ of $25 \mathrm{mM} \mathrm{MgCl}_{2}, 0.5 \mu \mathrm{L}$ of $5 \mathrm{U} / \mu \mathrm{L}$ Taq Polymerase (Sigma Aldrich, Shanghai, China), and 10 nano-grams (ng) of template DNA. The procedure was initially denatured at $94{ }^{\circ} \mathrm{C}$ for 7 minutes, followed by 30 denaturation cycles at $94{ }^{\circ} \mathrm{C}$ for 60 seconds, annealing at $52{ }^{\circ} \mathrm{C}$ for 60 seconds, and elongation at $65{ }^{\circ} \mathrm{C} 8$ minutes, followed by a 10 minutes extension at $65^{\circ} \mathrm{C}$. The ERIC-PCR products were isolated by electrophoresis (100 voltage, 30 minutes) in agarose gel (1.5\%), with the DNA marker DL5000 (Takara, Japan), and the electrophoresis results were observed and photographed in the gel imaging system (Bio-Rad, USA).

\section{Detection of bacterial relative gene expression levels}

Detection of small intestinal bacterial relative gene expression levels was performed according to the method described by Dewar et al. (2017). The quantitative fluorescence PCR was performed with the CFX 96 instrument (Bio-Rad, USA), using a Takara ExTaq RTPCR kit and SYBR Green as the detection dye (Takara, Japan). The reaction system and procedure of the quantitative fluorescence PCR were operated according to the Prime Script ${ }^{\mathrm{TM}}$ RT reagent Kit manual operation (TaKaRa, Japan). The relative gene expression levels of genes were normalized to $\beta$-actin and $18 S$ using the $2^{-\Delta \Delta \mathrm{Ct}}$ method (Livak and Schmittgen, 2001). Table 1 listed the quantitative fluorescence PCR Primers (BGI, Beijing, China).

Table 1. Primers for quantitative fluorescence quantitative PCR

\begin{tabular}{llcc}
\hline Gene name & Primers & Product size (bp) & Reference \\
\hline Escherichia coli & $\begin{array}{l}\text { F: TACCCGCAGAAGAAGCACC } \\
\text { R: CGCATTTCACCGCTACACC }\end{array}$ & 215 & Ren et al. 2012 \\
\hline Enterobacter & $\begin{array}{l}\text { F: CATTGACGTTACCCGCAGAAGAAGC } \\
\text { R: CTCTACGAGACTCAAGCTTGC }\end{array}$ & 195 & Lu, et al., 2019 \\
\hline Enterococcus & $\begin{array}{l}\text { F: CCCTTATTGTTAGTTGCCATATT } \\
\text { R: CTCTACGAGACTCAAGCTTGC }\end{array}$ & 144 & Bartosch, et al., 2004 \\
\hline $18 S$ & $\begin{array}{l}\text { F: TTGGTGGAGCGATTTGTC } \\
\text { R: ATCTCGGGTGGCTGAACG }\end{array}$ & 129 & Benjamino and Graf, 2016 \\
\hline$\beta$-actin & $\begin{array}{l}\text { F: CAACGAGCGGTTCAGGTGT } \\
\text { R: TGGAGTTGAAGGTGGTCTCG }\end{array}$ & 92 & Feng et al. 2012 \\
\hline F= forward primer, $\mathrm{R}=$ reverse primer, bp = base pair. & &
\end{tabular}

\section{Data analysis}

The gel imaging system was used to take pictures of the stained gel and Quantity One image analysis software
(Bio-Rad, USA) was used for ERIC-PCR image analysis. Using SAS 9.2 (SAS Institute, USA), the comparisons of several groups were analyzed by General Liner Model 
(GLM), and the means were assessed for significant differences using the SNK-q test. All results were expressed as means \pm Standard Deviation and p-value below 0.05 was considered statistically significant.

\section{RESULTS}

\section{Influence of overfeeding on slaughter performance}

As shown in table 2, overfeeding could significantly increase body weight, slaughter weight, abdominal fat pad weight, subcutaneous adipose tissue weight, and the liver weight of Tianfu Meat goose and Gang goose ( $<<0.05)$. After overfeeding, there was no significant difference between the body weight, slaughter weight, and abdominal fat weight of the two goose breeds $(p>0.05)$. However, the liver weight of Tianfu Meat goose was higher than that of Gang goose, and the subcutaneous adipose tissue weight of Gang goose was higher than that of Tianfu Meat goose after overfeeding $(\mathrm{p}<0.05)$.

\section{Influence of overfeeding on intestinal morphology}

As shown in table 3, duodenal weight, duodenal length, jejunum weight, ileum weight, and ileum length obviously increased in both Tianfu Meat goose and Gang goose after overfeeding $(\mathrm{p}<0.05)$. The villi height, the crypt depth, and the wall thickness of different small intestinal segments were measured, the results are shown in table 4 . The wall thickness became thin except for the jejunum of the Gang goose after overfeeding $(\mathrm{p}<0.05)$. Overfeeding increased the villus height of all small intestinal segments of two breeds ( $p<0.05)$. Compared to the control group, the crypt depth of all small intestine parts in the overfed group of Tianfu Meat goose decreased $(\mathrm{p}<0.05)$. The ratio of villus height to crypt depth of Tianfu Meat goose after overfeeding was higher than that of Gang goose in duodenum and ileum $(\mathrm{p}<0.05)$.

\section{Influence of overfeeding on digestive enzyme activity in small intestine}

As shown in table 5, the activity of amylase, and chymotrypsin significantly in the duodenum of two breeds decreased after overfeeding $(p<0.05)$. The activity of maltase, invertase, and chymotrypsin increased significantly in the jejunum of Gang goose after overfeeding $(\mathrm{p}<0.05)$. The activity of amylase, chymotrypsin, and maltase in the ileum of the Gang goose decreased significantly after overfeeding $(p<0.05)$. The activity of amylase and chymotrypsin decreased and the activity of invertase and maltase increased in the ileum of Tianfu Meat goose after overfeeding $(\mathrm{p}<0.05)$. Compared to the overfed group of Gang goose, the activity of maltase and invertase in the duodenum and ileum of Tianfu Meat goose overfed group was higher $(\mathrm{p}<0.05)$.

\section{ERIC-PCR results of the small intestinal microbiota after overfeeding}

Figure 1 indicates that the ERIC-PCR amplified bands, which were bigger than 500 base pair (bp), had the greatest difference between the control group and the overfed group in each intestinal segment of the overfed group. The number of amplified bands of intestinal microbiota in each intestinal segment of the Gang goose overfeeding group was less than that of the control group. In contrast, the number of amplified bands of intestinal microbiota was increased in each intestinal segment in Tianfu Meat goose after overfeeding.

The Quantity One Analysis Software was used to analyze the similarity of the ERIC-PCR map (Figure 2). In comparison, it was intuitive to see that the difference in the composition of the intestinal microbiota is between different intestinal segments. The similar index between the microbiota in different intestinal segments varied from 0.13 to 1.00 . The cluster analysis indicated that forcefeeding had an obvious influence on the intestinal microbiota in both goose breeds.

\section{Overfeeding influence on the bacterial distribution in each intestinal segments}

The Relative gene expression level of bacteria in the duodenum is shown in figure $3 \mathrm{~A}$. The gene expression of Enterobacter was higher in the Tianfu Meat goose than in the Gang goose $(\mathrm{p}<0.05)$. There was no significant difference in Escherichia coli and Enterococcus gene expression between two breeds after overfeeding ( $\mathrm{p}>$ 0.05 ). The relative gene expression level of bacteria in the jejunum is shown in figure 3B. The gene expression of $E$. coli and Enterococcus in the jejunum had no significant difference between the Tianfu Meat goose and the Gang goose after overfeeding ( $p>0.05)$. Enterobacter gene expression of the Gang goose was higher than Tianfu Meat goose $(\mathrm{p}<0.05)$. In figure $3 \mathrm{C}$, the relative gene expression level of bacteria in the ileum was shown. There was no significant difference in Escherichia coli and Enterococcus gene expression in the ileum between two breeds after overfeeding ( $\mathrm{p}>0.05$ ). However, Escherichia coli gene expression in Tianfu Meat goose decreased after overfeeding $(\mathrm{p}<0.05)$. 
Wei et al., 2020

Table 2. Comparison of overfeeding influence on the slaughter performance between Gang goose and Tianfu Meat goose

\begin{tabular}{lcccc}
\hline Characteristics & $\begin{array}{c}\text { Control group of } \\
\text { Gang goose }\end{array}$ & $\begin{array}{c}\text { Overfed group of } \\
\text { Gang goose }\end{array}$ & $\begin{array}{c}\text { Control group of } \\
\text { Tianfu Meat goose }\end{array}$ & $\begin{array}{c}\text { Overfed group of } \\
\text { Tianfu Meat goose }\end{array}$ \\
\hline Alive body weight & $4189.66 \pm 436.31^{\mathrm{b}}$ & $6099.51 \pm 805.15^{\mathrm{a}}$ & $4027.94 \pm 468.44^{\mathrm{b}}$ & $6282.11 \pm 566.29^{\mathrm{a}}$ \\
Slaughter weight & $3496.15 \pm 1007.10^{\mathrm{b}}$ & $5533.63 \pm 688.32^{\mathrm{a}}$ & $3385.19 \pm 367.43^{\mathrm{b}}$ & $5679.26 \pm 519.89^{\mathrm{a}}$ \\
Abdominal fat weight & $96.44 \pm 29.73^{\mathrm{b}}$ & $366.51 \pm 81.93^{\mathrm{a}}$ & $97.61 \pm 35.97^{\mathrm{b}}$ & $428.13 \pm 120.18^{\mathrm{a}}$ \\
Subcutaneous fat weight & $632.13 \pm 46.38^{\mathrm{c}}$ & $1440.46 \pm 184.84^{\mathrm{a}}$ & $440.52 \pm 63.37^{\mathrm{d}}$ & $1240.96 \pm 104.16^{\mathrm{b}}$ \\
Liver weight & $60.6 \pm 6.04^{\mathrm{c}}$ & $266.54 \pm 37.52^{\mathrm{b}}$ & $54.35 \pm 8.07^{\mathrm{c}}$ & $397.94 \pm 80.02^{\mathrm{a}}$ \\
\hline Values are means \pm Standard Deviation $(\mathrm{n}=25) .{ }^{\mathrm{a}, \mathrm{b}, \mathrm{c}, \mathrm{d}}=$ values within the same row with different superscripts mean significant difference $(\mathrm{p}<0.05) . \mathrm{g}=$ gram.
\end{tabular}

Table 3. Comparison of overfeeding influence on the weight and length of the small intestine between Gang goose and Tianfu Meat goose

\begin{tabular}{lcccc}
\hline Characteristics & $\begin{array}{c}\text { Control group of } \\
\text { Gang goose }\end{array}$ & $\begin{array}{c}\text { Overfed group of } \\
\text { Gang goose }\end{array}$ & $\begin{array}{c}\text { Control group of } \\
\text { Tianfu Meat goose }\end{array}$ & $\begin{array}{c}\text { Overfed group of } \\
\text { Tianfu Meat goose }\end{array}$ \\
\hline Duodenal weight $(\mathrm{g})$ & $8.85 \pm 1.22^{\mathrm{c}}$ & $24.74 \pm 7.51^{\mathrm{a}}$ & $8.85 \pm 0.93^{\mathrm{c}}$ & $15.32 \pm 2.41^{\mathrm{b}}$ \\
Duodenal length $(\mathrm{cm})$ & $37.75 \pm 11.06^{\mathrm{b}}$ & $53.10 \pm 10.96^{\mathrm{a}}$ & $32.38 \pm 1.49^{\mathrm{b}}$ & $47.60 \pm 5.14^{\mathrm{a}}$ \\
Jejunal weight $(\mathrm{g})$ & $16.38 \pm 3.16^{\mathrm{b}}$ & $24.98 \pm 3.50^{\mathrm{a}}$ & $16.55 \pm 0.94^{\mathrm{b}}$ & $23.00 \pm 1.88^{\mathrm{a}}$ \\
Jejunal length $(\mathrm{cm})$ & $59.75 \pm 6.30^{\mathrm{b}}$ & $73.90 \pm 5.55^{\mathrm{a}}$ & $74.00 \pm 2.94^{\mathrm{a}}$ & $75.90 \pm 4.39^{\mathrm{a}}$ \\
Ileal weight $(\mathrm{g})$ & $16.20 \pm 2.53^{\mathrm{b}}$ & $23.86 \pm 3.45^{\mathrm{a}}$ & $15.15 \pm 4.52^{\mathrm{b}}$ & $21.48 \pm 1.89^{\mathrm{a}}$ \\
Ileal length $(\mathrm{cm})$ & $59.25 \pm 11.64^{\mathrm{b}}$ & $85.40 \pm 9.04^{\mathrm{a}}$ & $70.75 \pm 4.99^{\mathrm{b}}$ & $88.2 \pm 18.72^{\mathrm{a}}$ \\
\hline
\end{tabular}

Values are means \pm Standard Deviation $(\mathrm{n}=25),{ }^{\mathrm{a}, \mathrm{b}, \mathrm{c}}=$ values within the same row with different superscripts mean significant difference $(\mathrm{p}<0.05) . \mathrm{g}=\mathrm{gram}, \mathrm{cm}=$ centimeter.

Table 4. Comparison of overfeeding influence on small intestinal histology between Gang goose and Tianfu Meat goose

\begin{tabular}{|c|c|c|c|c|c|}
\hline \multicolumn{2}{|c|}{ Intestinal section } & $\begin{array}{c}\begin{array}{c}\text { Control group of } \\
\text { Gang goose }\end{array} \\
379.74 \pm 57.58^{\mathrm{c}}\end{array}$ & $\begin{array}{c}\begin{array}{c}\text { Overfed group of } \\
\text { Gang goose }\end{array} \\
426.67 \pm 133.85^{\mathrm{b}}\end{array}$ & $\begin{array}{c}\begin{array}{c}\text { Control group of } \\
\text { Tianfu Meat goose }\end{array} \\
393.28 \pm 102.49^{\mathrm{c}}\end{array}$ & $\begin{array}{c}\begin{array}{c}\text { Overfed group of } \\
\text { Tianfu Meat goose }\end{array} \\
526.25 \pm 77.82^{\mathrm{a}}\end{array}$ \\
\hline \multirow{2}{*}{ Duodenum } & Crypt depth $(\mu \mathrm{m})$ & $129.06 \pm 28.95^{\mathrm{a}}$ & $123.44 \pm 19.07^{\mathrm{a}}$ & $142.07 \pm 42.84^{\mathrm{a}}$ & $98.05 \pm 21.96^{\mathrm{b}}$ \\
\hline & Gut wall thickness $(\mu \mathrm{m})$ & $227.38 \pm 125.70^{\mathrm{b}}$ & $189.54 \pm 46.57^{\mathrm{c}}$ & $466.48 \pm 169.32^{\mathrm{a}}$ & $237.54 \pm 108.36^{\mathrm{b}}$ \\
\hline \multirow{2}{*}{ Jejunum } & Villus height $(\mu \mathrm{m})$ & $301.54 \pm 46.45^{\mathrm{d}}$ & $509.27 \pm 136^{\mathrm{a}}$ & $395.15 \pm 150.42^{\mathrm{c}}$ & $444.01 \pm 215.55^{\mathrm{b}}$ \\
\hline & Crypt depth $(\mu \mathrm{m})$ & $129.96 \pm 30.64^{\mathrm{b}}$ & $123.08 \pm 23.28^{\mathrm{b}}$ & $188.47 \pm 63.76^{\mathrm{a}}$ & $98.17 \pm 214.23^{\mathrm{c}}$ \\
\hline \multirow{4}{*}{ Ileum } & Villus height $(\mu \mathrm{m})$ & $332.35 \pm 117.04^{\mathrm{b}}$ & $423.11 \pm 89.58^{\mathrm{a}}$ & $303.07 \pm 48.03^{\mathrm{b}}$ & $379.46 \pm 46.2^{\mathrm{a}}$ \\
\hline & Crypt depth $(\mu \mathrm{m})$ & $106.01 \pm 26.57^{\mathrm{b}}$ & $121.69 \pm 27.61^{\mathrm{a}}$ & $99.69 \pm 26.33^{\mathrm{b}}$ & $85.51 \pm 18.93^{\mathrm{c}}$ \\
\hline & Villus/crypt ratio & $3.44 \pm 1.77^{\mathrm{b}}$ & $3.68 \pm 1.22^{\mathrm{b}}$ & $3.20 \pm 0.78^{\mathrm{b}}$ & $4.63 \pm 1.07^{\mathrm{a}}$ \\
\hline & Gut wall thickness $(\mu \mathrm{m})$ & $442.86 \pm 279.94^{\mathrm{a}}$ & $177.9 \pm 41.13^{\mathrm{d}}$ & $338.15 \pm 157.64^{\mathrm{b}}$ & $258.93 \pm 139.6^{\mathrm{c}}$ \\
\hline
\end{tabular}

Table 5. Comparison of overfeeding influence on small intestinal digestive enzyme activity between Gang goose and Tianfu Meat goose

\begin{tabular}{|c|c|c|c|c|c|}
\hline \multicolumn{2}{|c|}{ Intestinal section } & $\begin{array}{c}\begin{array}{c}\text { Control group of } \\
\text { Gang goose }\end{array} \\
371.57 \pm 76.01^{\mathrm{a}}\end{array}$ & $\begin{array}{c}\begin{array}{c}\text { Overfed group of } \\
\text { Gang goose }\end{array} \\
283.36 \pm 120.69^{\mathrm{b}}\end{array}$ & $\begin{array}{c}\begin{array}{c}\text { Control group of } \\
\text { Tianfu Meat goose }\end{array} \\
374.09 \pm 90.05^{\mathrm{a}}\end{array}$ & $\begin{array}{c}\begin{array}{c}\text { Overfed group of } \\
\text { Tianfu Meat goose }\end{array} \\
264.48 \pm 59.91^{\mathrm{b}}\end{array}$ \\
\hline \multirow{2}{*}{ Duodenum } & Amylase (U / mgprot) & $6407.23 \pm 317.92^{\mathrm{a}}$ & $4624.37 \pm 241.80^{\mathrm{b}}$ & $6545.65 \pm 291.29^{\mathrm{a}}$ & $5046.17 \pm 524.72^{\mathrm{b}}$ \\
\hline & Maltase (U / mgprot) & $4700.95 \pm 345.56^{\mathrm{b}}$ & $3088.29 \pm 364.67^{\mathrm{b}}$ & $6508.92 \pm 415.00^{\mathrm{a}}$ & $6038.36 \pm 336.35^{\mathrm{a}}$ \\
\hline \multirow{3}{*}{ Jejunum } & Chymotrypsin ( U / mgprot) & $157.72 \pm 20.00^{\mathrm{b}}$ & $200.42 \pm 56.57^{\mathrm{a}}$ & $137.36 \pm 17.32^{\mathrm{b}}$ & $148.44 \pm 16.27^{\mathrm{b}}$ \\
\hline & Amylase (U / mgprot) & $5278.36 \pm 261.53$ & $5950.41 \pm 532.03$ & $5259.59 \pm 189.00$ & $5387.69 \pm 195.89$ \\
\hline & Maltase (U / mgprot) & $5781.68 \pm 750.08^{\mathrm{b}}$ & $7928.71 \pm 918.54^{\mathrm{a}}$ & $3529.73 \pm 560.71^{\mathrm{c}}$ & $3282.79 \pm 544.71^{\mathrm{c}}$ \\
\hline \multirow{4}{*}{ Ileum } & Chymotrypsin ( U / mgprot) & $140.84 \pm 20.15^{\mathrm{a}}$ & $87.73 \pm 1.94^{\mathrm{b}}$ & $219.74 \pm 12.34^{\mathrm{a}}$ & $83.73 \pm 26.62^{\mathrm{b}}$ \\
\hline & Amylase (U / mgprot) & $5658.06 \pm 183.10^{\mathrm{b}}$ & $4495.21 \pm 196.86^{\mathrm{c}}$ & $7118.45 \pm 168.24^{\mathrm{a}}$ & $5328.67 \pm 165.74^{\mathrm{b}}$ \\
\hline & Invertase (U / mgprot) & $869.08 \pm 129.69^{c}$ & $766.17 \pm 147.12^{\mathrm{c}}$ & $1138.15 \pm 156.47^{\mathrm{b}}$ & $1314.76 \pm 136.02^{\mathrm{a}}$ \\
\hline & Maltase (U / mgprot) & $4645.29 \pm 323.60^{\mathrm{a}}$ & $3927.61 \pm 195.76^{\mathrm{b}}$ & $2785.75 \pm 167.45^{\mathrm{c}}$ & $4645.29 \pm 223.61^{\mathrm{a}}$ \\
\hline
\end{tabular}




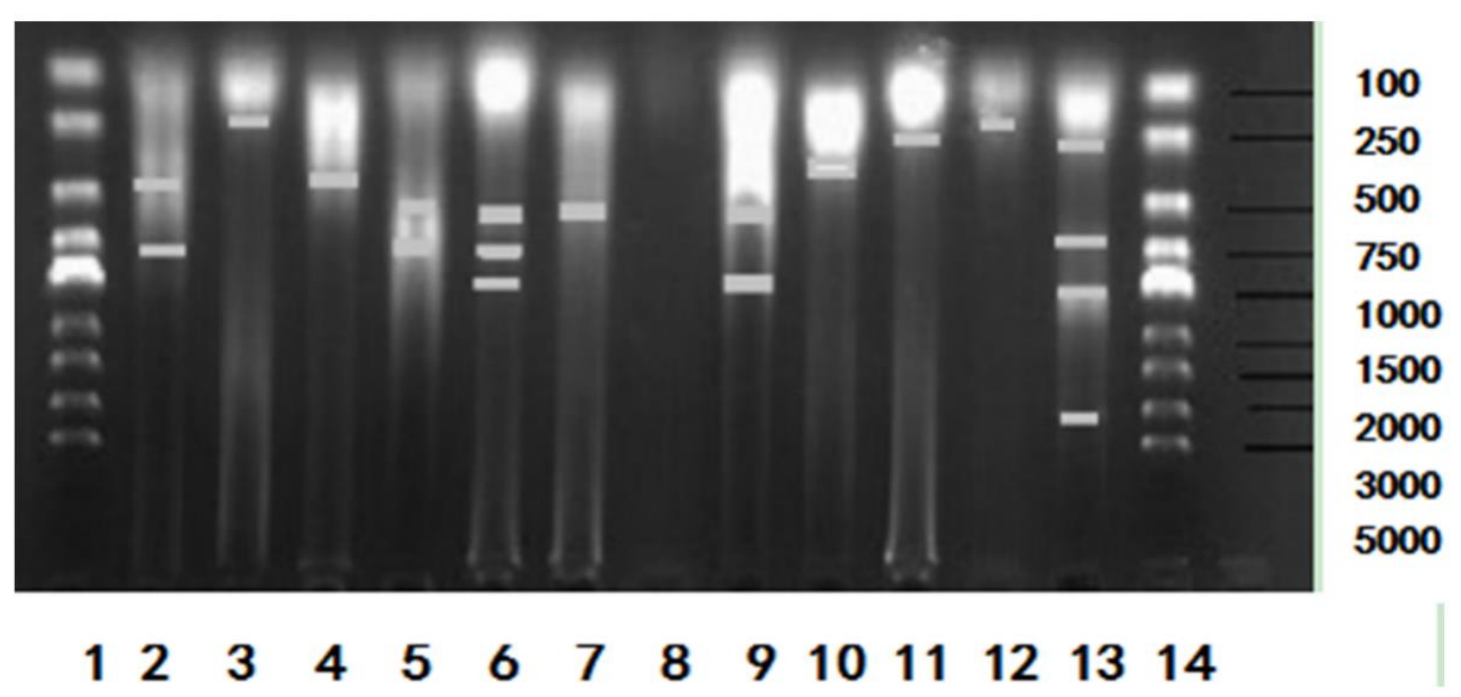

Figure 1. ERIC-PCR results of the intestinal microbiota in Gang goose and Tianfu Meat goose. 1 and 14: DNA marker DL5000; 2: duodenal microbiota of the control group of Gang goose; 3: duodenal microbiota of the overfeed group of Gang goose; 4: duodenal microbiota of the control group of Tianfu Meat goose; 5: duodenal microbiota of the overfeed group of Tianfu Meat goose; 6: jejunal microbiota of the control group of Gang goose; 7: jejunal microbiota of the overfeed group of Gang goose; 8: jejunal microbiota of the control group of Tianfu Meat goose; 9: jejunal microbiota of overfeed group of Tianfu Meat goose; 10: ileum microbiota of the control group of Gang goose; 11: ileum microbiota of the overfeed group of Gang goose; 12: ileum microbiota of the control group of Tianfu Meat goose; 13: ileum microbiota of the overfeed group of Tianfu Meat goose.

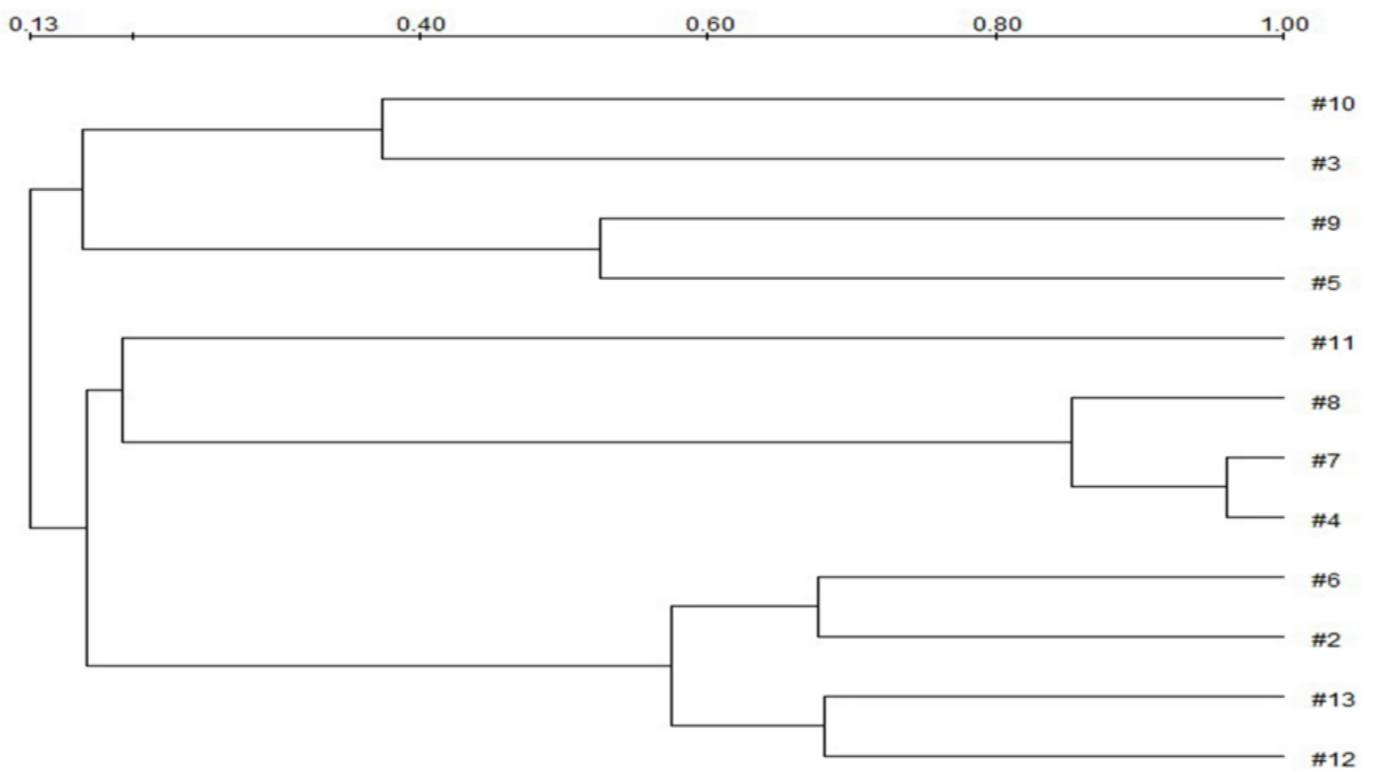

Figure 2. The dendrogram of ERIC-PCR in the intestinal microbiota of Gang goose and Tianfu Meat goose. \#2: duodenum microbiota of the control group of Gang goose; \#3: duodenum microbiota of the overfeed group of Gang goose; \#4: duodenum microbiota of the control group of Tianfu Meat goose; \#5: duodenum microbiota of the overfeed group of Tianfu Meat goose; \#6: jejunum microbiota of the control group of Gang goose; \#7: jejunum microbiota of the overfeed group of Gang goose; \#8: jejunum microbiota of the control group of Tianfu Meat goose; \#9: jejunum microbiota of the overfeed group of Tianfu Meat goose; \#10: ileum microbiota of the control group of Gang goose; \#11: ileum microbiota of the overfeed group of Gang goose; \#12: ileum microbiota of the control group of Tianfu Meat goose; \#13: ileum microbiota of the overfeed group of Tianfu Meat goose. 
A

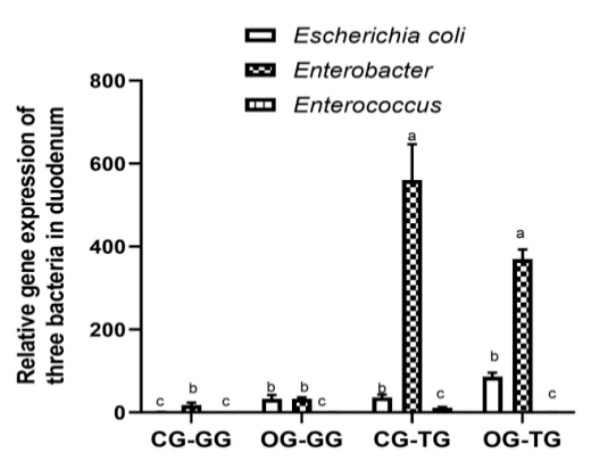

B

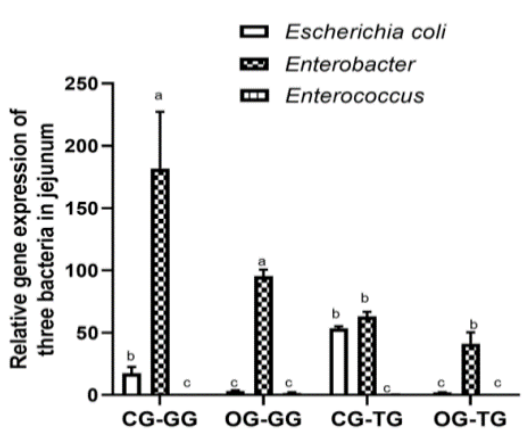

C

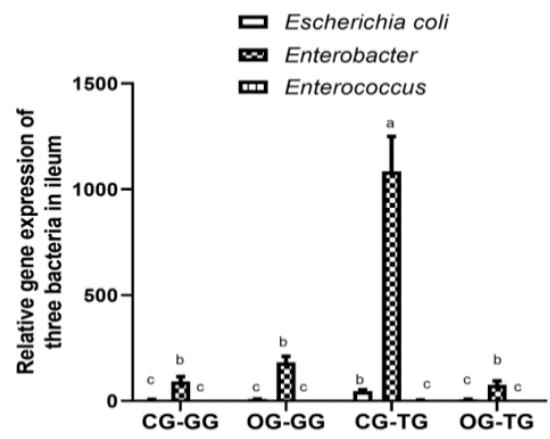

Figure 3. Relative gene expression level of bacteria in small intestine of Gang goose and Tianfu Meat goose. CG-GG: control group of Gang goose; OG-GG: overfed group of Gang goose; CG-TG: control group of Tianfu Meat goose; OG-TG: overfed group of Tianfu Meat goose. The experimental values are the means \pm Standard Deviation $(n=5) .{ }^{a, b}, c=$ The different lowercase above the bars represent significant differences $(\mathrm{p}<0.05)$.

\section{DISCUSSION}

The main purpose of overfeeding was to increase body fat deposition and produce foie gras in ducks and geese. The impact of overfeeding on production performance has been well discussed in waterfowl (Wen et al., 2016). The present study found similar results that body weight and liver weight increased, and fat was deposited in the subcutaneous and abdominal areas. Overfeeding-induced synthesis of triglycerides (TG) in the liver and peripheral adipose tissue could lead to a significant accumulation of TG in the liver and in the peripheral adipose tissue (Davail et al., 2000; Liu et al., 2020). Overfeeding induced a significant increase in liver weight (Arroyo et al., 2017; Liu et al., 2019). In the present trial, liver weight and subcutaneous fat weight increased significantly in the overfed group. Tianfu Meat goose's liver weight was higher than that of Gang goose after overfeeding, indicating that Tianfu Meat goose performed better for foie gras production. The subcutaneous adipose tissue weight of Gang goose was higher than that of Tianfu Meat goose after overfeeding, indicating that Gang goose had better fat storage capacity in subcutaneous adipose tissue.

The small intestine is the main place where the nutrient is digested and absorbed, which plays an important role in the digestion, absorption, and transportation of nutrients (El Aidy et al., 2015; Lamot, et al., 2019). Mitchell and Smith studied three broiler strains with different growth rate. The result indicated that the fastest growing strain had the highest absolute intestinal weight and length (Mitchell and Smith, 1991). Abdelfattah-Hassan and El-Ghazaly (2019) reported that the small intestine length of the duck increased, the villi length increased after the addition of organic acids to duckdiet, and the digestion and absorption surface area increased. Significant differences in the duodenum weight and length, the jejunum weight, the ileum weight and length were observed in the present research, indicating that the intestine accelerated its own growth and development to adapt to the high-intensity digestion and absorption.

The integrity of the intestinal mucosa morphology is the basis for maintaining normal intestinal physiological activity in animals (Houshmand et al., 2012). The villus height, crypt depth, the ratio of the villus to crypt and wall thickness of the small intestine are important indicators to measure the function of small intestine digestion and absorption (Simon et al., 2019). The higher the height of villi, the greater the number of intestinal epithelial cells. The larger the contact area in which the small intestinal mucosa is in contact with nutrients, the greater the nutrients absorption (Caspary, 1992; Abdelfattah-Hassan and El-Ghazaly, 2019). The depth of the crypt reflects the rate of proliferation and maturity of the crypt cells. The crypt becomes shallow, indicating that maturation rate of crypt cell increased, the secretion function enhanced (AlFataftah and Abdelqader, 2014), and the crypt cells migrate and differentiate from the base of the crypt to the end of a villus from which the absorptive chorionic villi and supplement normal exfoliated chorionic epithelium (Yang et al., 2016). The higher ratio of villus height to crypt depth reflects higher nutrient absorption capacity (Wu et al., 2004; Li et al., 2019). The villus height, the ratio of villus height to crypt depth increased and the crypt depth became shallow in intestine of Tianfu Meat goose and some segments of Gang goose intestine after 
overfeeding, which explained that the intestinal absorption capacity increased. Compared to the Gang goose, the ratio of villus height to crypt depth of the Tianfu Meat goose after overfeeding was higher in the duodenum and in the ileum, which indicated that the intestinal absorption capacity of the Tianfu Meat goose was higher than that of Gang goose. The thickness of the small intestinal mucous membrane and myometrium is closely related to the rhythmic contraction of the small intestine and the efficiency of the mechanical digestion of the chyme. However, in the present experiment, the intestinal wall thickness decreased after overfeeding. This was possibly due to the physical expansion caused by overfeeding, on the other hands the thickness became thin, which was beneficial for the diffusion absorption dependent on the nutrients concentration.

Animals have to digest all kinds of nutrients under the action of digestive enzymes. In the present experiment, amylase activity decreased, but some other digestive enzyme activities increased after overfeeding. These changes ensured that nutrients were fully utilized. When overfeed, a large number of carbohydrates obtained from geese were converted into blood sugar, which continuously supplied the liver with the synthesize TG, so that the rate of using blood glucose to synthesize TG in the liver of geese would increase dramatically. When the synthesis of TG in the liver exceeded the secretion of apolipoprotein and the rate of fatty acids $\beta$-oxidation, fat began to accumulate in the liver (Fournier et al., 1997). Invertase and maltase are disaccharidase and catalyze disaccharide that was created by cracking starch in glucose. The activity of invertase and maltase from Tianfu Meat goose was higher in the duodenum and ileum and lower in the jejunum than that of Gang goose after overfeeding. In combination with the present trail the total length of duodenum and ileum was longer than the length of jejunum, so that the activity of invertase and maltase from Tianfu Meat goose after overfeeding in the small intestine was higher than that of Gang goose. As previously mentioned, the ratio of villus height to crypt depth of the Tianfu Meat goose after overfeeding, was higher than that of the Gang goose. So, the digestionabsorption capacity of Tianfu Meat goose was higher than that of Gang goose. Thereby, more glucose was absorbed into blood and TG was synthesized in the liver of Tianfu Meat goose, and the liver weight of Tianfu Meat goose was higher than that of Gang goose after overfeeding.

In the present study, the ERIC-PCR fingerprint technique was applied to analyze the community structure of the small intestinal microbiota. The experimental results indicated that overfeeding decreased the band number of intestinal bacteria in each intestinal segment of Gang goose and increased the band number of intestinal bacteria in each intestinal segment of Tianfu Meat goose, indicating that the small intestinal microbial diversity was significantly influenced by overfeeding, which was similar to the finding reported by Vasai et al. (2014). The reduction in intestinal microbial diversity reduces intestinal homeostasis and resistance to pathogens (Mountzouris et al., 2015; Das et al., 2019). The overfeeding and intestinal homeostasis of Tianfu Meat goose was, therefore, higher than that of Gang goose. However, the bacterial species represented by the specific bands of each segment, still need to be investigated.

It has been found in the livestock, the Escherichia coli are pathogenic bacteria (Kittler et al., 2020; Xu et al., 2020; Yuan et al., 2020). Enterococcus faecium belongs to Lactobacillus, and is a normal beneficial bacterium in the gastrointestinal tract of mammals (Zhao et al., 2013; Shanmugasundaram et al., 2019). It was reported that when Enterobacter cloacae B-29 is given orally to germfree mice and providing the high-fat diet could induce obesity and insulin resistance in mice (Fei and Zhao, 2013). Therefore, Enterococcus, Escherichia coli, and Enterobacteria were selected for analysis in the present study, and the overfeeding effect on the gene expression level of the three bacteria in different intestinal segments of Gang goose and Tianfu Meat goose was measured. The general distribution ratio of Enterococcus, Enterobacter, and Escherichia coli was similar in each part of the intestine (Enterobacter $>$ Escherichia coli $>$ Enterococcus) in the groups of Gang goose and Tianfu Meat goose. Pathogenic bacteria entering the intestinal tract reduce the species and number of intestinal microorganisms by producing toxins and harmful substances and reducing the diversity of intestinal flora (Barman et al., 2008; Ayiku et al., 2020). In the present study, there was no significant difference in the gene expression of Enterococcus. The gene expression of Escherichia coli decreased after overfeeding in Tianfu Meat goose. Therefore, intestinal microbiota had better stability in Tianfu Meat goose. The Enterobacter gene expression of Gang goose was higher in the jejunum and ileum and lower in the duodenum than that of Tianfu Meat goose before overfeeding. The Enterobacter gene expression of Gang goose was higher in the jejunum and lower in the duodenum than that of Tianfu Meat goose after overfeeding, furthermore, the total length of the jejunum and ileum was longer than the length of the duodenum, so that the number of Enterobacter in the small intestine of the Gang goose 
overfeeding group was greater compared to the Tianfu Meat goose overfeeding group. The subcutaneous adipose tissue weight of Gang goose was higher than that of Tianfu Meat goose after overfeeding. This was consistent with new research that Enterobacter cloacae administration induced subcutaneous fat accumulation in mice fed high-fat diet (Keskitalo et al., 2018).

\section{CONCLUSION}

In conclusion, the liver weight, lipid deposition in the liver, the digestion-absorption capacity, gut microbiota diversity, and gut microbiota stability of the Tianfu Meat goose after overfeeding were higher than those of the Gang goose. Thereby, Tianfu Meat goose is the better breed for foie gras production for prolonged overfeeding. The subcutaneous adipose tissue weight and small intestine Enterobacter gene expression of Gang goose were higher than those of Tianfu Meat goose after overfeeding, so Gang goose is suited to overfeeding in a short time for gain body weight and subcutaneous fat as an overfed duck for roast duck.

\section{DECLARATION}

\section{Acknowledgements}

This research was supported by the National Natural Science Funds of China (No. 31672413) and the China Agricultural Research System (No. CARS- 42- 4).

\section{Competing interest}

We declare that all authors have no conflict of interest in this manuscript.

\section{Author's contributions}

The experiments were conceived and designed by Chunchun Han, and Rongxue Wei and were performed by Fengjiang Ye, Fang He, Qi Song, and Xiangping Xiong. Wenlan Yang and Xianyin Zeng carried out the data analysis. Reagents, materials, and analysis tools were contributed by Ling Chen, Hongyong Xu, and Liang Li. Hehe Liu was administered the project. The draft manuscript was written by Chunchun Han and Rongxue Wei, and Rongxue Wei was also reviewed and edited the text of article. All authors were involved in the general discussions of the data and implications.

\section{Consent to publish}

All authors submitted their informed consent prior to their inclusion in the study.

\section{REFERENCES}

Abdelfattah-Hassan A and El-Ghazaly HM (2019). Effects of diet's acidifying additives on the intestinal histomorphology in ducks. Slovenian Veterinary Research, 56:219-228. DOI: https:// doi.org/10.26873/svr-760-2019

Al-Fataftah AR and Abdelqader A (2014). Effects of dietary bacillus subtilis on heat-stressed broilers performance, intestinal morphology and microflora composition. Animal Feed Science and Technology, 198: 279-285 DOI: https:// doi.org/10.1016/j.anifeedsci.2014.10.012A

Arroyo J, Lavigne F, Bannelier C and Fortun-Lamothe L (2017). Influence of the incorporation mode of sugar beet pulp in the finishing diet on the digestive tract and performances of geese reared for foie gras production. Poultry Science, 96 (11): 39283937. DOI: https:// doi.org/10.3382/ps/pex 210

Ayiku, S, S Jianfei B-P Tan, XH Dong and Liu HY (2020). Effects of dietary yeast culture on shrimp growth, immune response, intestinal health, and disease resistance against Vibrio harveyi. Fish and Shellfish Immunology, 102: 286-95. DOI: https:// doi.org/10.1016/j.fsi.2020.04.036

Barman M, Unold D, Shifley K, Amir E, Hung K, Bos N and Salzman N (2008). Enteric salmonellosis disrupts the microbial ecology of the murine gastrointestinal tract. Infection and Immunity, 76 (3): $907-$ 915. DOI: https:// doi.org/10.1128/iai.01432-07

Bartosch S, Fite A, Macfarlane GT and McMurdo MET (2004). Characterization of bacterial communities in feces from healthy elderly volunteers and hospitalized elderly patients by using realtime PCR and effects of antibiotic treatment on the fecal microbiota. Applied and Environmental Microbiology, 70: 35753581. DOI: https:// doi.org/10.1128/aem.70.6.3575-3581.2004

Benjamino J and Graf J (2016). Characterization of the core and castespecific microbiota in the termite, reticulitermes flavipes. Frontiers in Microbiology, 7. DOI: https:// doi.org/10.3389/fmicb.2016.00171

Cao W, Liu G, Fang T, Wu X, Jia G, Zhao H, Chen X, Wu C, Wang J and Cai J (2015). Effects of spermine on the morphology, digestive enzyme activities, and antioxidant status of jejunum in suckling rats. Rsc Advances, 5 (93): 76607-76614. DOI: https:// doi.org/10.1039/c5ra15793e

Cao W, Xu X, Jia G, Zhao H, Chen X, Wu C, Tang J, Wang J, Cai J and Liu G (2018). Roles of spermine in modulating the antioxidant status and nrf 2 signalling molecules expression in the thymus and spleen of suckling piglets-new insight. Journal of Animal Physiology and Animal Nutrition, 102 (1): E183-E192. DOI: https:// doi.org/10.1111/jpn.12726

Caspary WF (1992). Physiology and pathophysiology of intestinal absorption. The American journal of clinical nutrition, 55:299S308S. DOI: https:// doi.org/10.1093/ajcn/55.1.299s

Das P, Babaei P and Nielsen J (2019). Metagenomic analysis of microbemediated vitamin metabolism in the human gut microbiome. Bmc Genomics, 20. DOI: https:// doi.org/10.1186/s12864-019-5591-7

Davail S, Guy G, Andre J, Hermier D and Hoo-Paris R (2000). Metabolism in two breeds of geese with moderate or large overfeeding induced liver-steatosis. Comparative biochemistry and physiology. Part A, Molecular \& integrative physiology, 126 (1): 91-99. DOI: https://doi.org/10.1016/s1095-6433 (00)00190-2

Dewar ML, Arnould JPY, Allnutt TR, Crowley T, Krause L, Reynolds J, Dann P and Smith SC (2017). Microbiota of little penguins and short-tailed shearwaters during development. Plos One, 12 (8). DOI: https:// doi.org/10.1371/journal.pone.0183117

El Aidy S, van den Bogert B and Kleerebezem M (2015). The small intestine microbiota, nutritional modulation and relevance for health. Current Opinion in Biotechnology, 32: 14-20. DOI: https:// doi.org/10.1016/j.copbio.2014.09.005 
Fei $\mathrm{N}$ and Zhao L (2013). An opportunistic pathogen isolated from the gut of an obese human causes obesity in germfree mice. Isme Journal, 7 (4): $\quad 880-884$. DOI:_https:// doi.org/10.1038/ismej.2012.153

Feng Y, Yang X J, Wang Y B, Li W L, Liu Y, Yin RQ and Yao JH (2012). Effects of immune stress on performance parameters, intestinal enzyme activity and mRNAexpression of intestinal transporters in broiler chickens. Asian-Australasian Journal of Animal Sciences, 25:701-707. DOI:_https:// doi.org/10.5713/ajas.2011.11377

Fournier E, Peresson R, Guy G and Hermier D (1997). Relationships between storage and secretion of hepatic lipids in two breeds of geese with different susceptibility to liver steatosis. Poultry Science, 76 (4): 599-607. DOI: https:// doi.org/10.1093/ps/76.4.599

Geng TY, Yang B, Li FY, Xia LL, Wang QQ, Zhao X and Gong DQ (2016). Identification of protective components that prevent the exacerbation of goose fatty liver: Characterization, expression and regulation of adiponectin receptors. Comparative Biochemistry and Physiology B-Biochemistry and Molecular Biology, 194: 32-38. DOI: https:// doi.org/10.1016/j.cbpb.2016.01.006

Houshmand M, Azhar K, Zulkifli I, Bejo MH and Kamyab A (2012). Effects of non-antibiotic feed additives on performance, immunity and intestinal morphology of broilers fed different levels of protein. South African Journal of Animal Science, 42 (1): 22-32. DOI: https:// doi.org/10.4314/sajas.v42i1.3

Keskitalo A, Munukka E, Toivonen R, Hollmen M, Kainulainen H Huovinen P, Jalkanen S and Pekkala S (2018). Enterobacter cloacae administration induces hepatic damage and subcutaneous fat accumulation in high-fat diet fed mice. Plos One, 13 (5): e019826. DOI: https:// doi.org/10.1371/journal.pone.0198262

Kittler S, Mengden R, Korf I., Bierbrodt A, Wittmann J, Plotz M, Jung A, Lehnherr T, Rohde C, Lehnherr H et al. (2020). Impact of bacteriophage-supplemented drinking water on the $E$. coli population in the chicken gut. Pathogens (Basel, Switzerland), 9. DOI: https:// doi.org/10.3390/pathogens9040293

Lamot DM, Sapkota D, Wijtten PJA, Anker I, Heetkamp MJW, Kemp B and Brand $H$ (2019). Diet density during the first week of life: Effects on growth performance, digestive organ weight, and nutrient digestion of broiler chickens. Poultry Science, 98:789-795. DOI: https:// doi.org/10.3382/ps/pey002

Li Y, Zhang LJ, Liu HY, Yang Y, He JQ, Cao M, Yang M, Zhong W, Lin Y, Zhuo Y et al. (2019). Effects of the ratio of insoluble fiber to soluble fiber in gestation diets on sow performance and offspring intestinal development. Animals, 9. DOI: https:// doi.org/10.3390/ani9070422

Liu L, Zhao X, Wang Q, Sun XX, Xia LL, Wang QQ, Yang B, Zhang YH, Montgomery S and Meng H (2016). Prosteatotic and protective components in a unique model of fatty liver: Gut microbiota and suppressed complement system. Scientific Reports, 6. DOI: https:// doi.org/10.1038/srep31763

Liu X, Li P, He C, Qu X and Guo S (2020). Comparison of overfed Xupu and Landes geese in performance, fatty acid composition, enzymes and gene expression related to lipid metabolism. Asian-Australasian journal of animal sciences. DOI: https:// doi.org/ 10.5713/ajas.19.0842

Liu X, Xu M, Qu X, Guo S, Liu Y, He C, He J and Liu W (2019). Molecular cloning, characterization, and expression analysis of adipocyte fatty acid binding protein gene in Xupu goose (Anser cygnoides domesticus). British Poultry Science 60:659-665. DOI: https:// doi.org/10.1080/00071668.2019.1655709

Livak KJ and Schmittgen TD (2001). Analysis of relative gene expression data using real-time quantitative PCR and the 2(-delta delta c (t)) method. Methods (San Diego, Calif.), 25 (4): 402-408. DOI: https:// doi.org/10.1006/meth.2001.1262

Lu Q, Lai J, Lu H, Ng C and Huang T, Zhang H, Ding K, Wang Z, Jiang $\mathrm{J}$ and $\mathrm{Hu} \mathbf{J}$ et al. (2019). Gut microbiota in bipolar depression and its relationship to brain function: an advanced exploration. Frontiers in Psychiatry, 10. DOI: https:// doi.org/ 10.3389/fpsyt.2019.00784

Mitchell MA and Smith MW (1991). The effects of genetic selection for increased growth rate on mucosal and muscle weights in the different regions of the small intestine of the domestic fowl (gallus domesticus). Comparative biochemistry and physiology. A Comparative Physiology, 99 (1-2): 251-258. DOI: https:// doi.org/ $\underline{10.1016 / 0300-9629(91) 90268-h}$

Mountzouris KC, Dalaka E, Palamidi I, Paraskeuas V, Demey V, Theodoropoulos G and Fegeros K (2015). Evaluation of yeast dietary supplementation in broilers challenged or not with salmonella on growth performance, cecal microbiota composition and salmonella in ceca, cloacae and carcass skin. Poultry Science, 94 (10): 2445-2455. DOI: https:// doi.org/ 10.3382/ps/pev243

Ren YN, J Li, XH Zhang, ZL Zeng, PP Zhen, DP Zeng, YH Liu and HX Jiang (2012). Contribution of Insertion Within acrR to acrAB Expression and Ciprofloxacin Resistance in a Veterinary Escherichia coli Isolate. Journal of Animal and Veterinary Advances, 11:2436-2439. Available at: http://docsdrive.com/pdfs/medwelljournals/javaa/2012/2436$\underline{2439 . p d f}$

Shanmugasundaram R, Mortada M, Murugesan GR and Selvaraj RK (2019). In vitro characterization and analysis of probiotic species in the chicken intestine by real-time polymerase chain reaction. Science, 98:5840-5846. DOI: https:// doi.org/ 10.3382/ps/pez188

Simon A, Gulyas G, Meszar Z, Bhide M, Olah J, Bai P, Csosz E, Javor A, Komlosi I and Remenyik J et al. (2019). Proteomics alterations in chicken jejunum caused by $24 \mathrm{~h}$ fasting. Peerj, 7. DOI: https:// doi.org/ 10.7717/peerj.6588

Staji H, Birgani SF and Raeisian B (2018). Comparative clustering and genotyping of campylobacter jejuni strains isolated from broiler and turkey feces by using RAPD-PCR and ERIC-PCR analysis. Annals of Microbiology, 68 (11): 755-762. DOI: https:// doi.org/ 10.1007/s13213-018-1380-9

Tang J, Fang Q, Lu M, Shao R, Shen J, Lu L and Niu D (2018). The effect of hydrated sodium calcium aluminosilicate on fatty liver and the composition of the intestinal microbiota in overfed landes geese. Brazilian Journal of Poultry Science, 20 (2): 393-402. DOI: https:// doi.org/ 10.1590/1806-9061-2017-0499

Vasai F, Ricaud KB, Bernadet MD, Cauquil L, Bouchez O, Combes S and Davail S (2014). Overfeeding and genetics affect the composition of intestinal microbiota in anas platyrhynchos (pekin) and cairina moschata (muscovy) ducks. Fems Microbiology Ecology. 87 (1): 204-216. DOI: https:// doi.org/ 10.1111/1574$\underline{6941.12217}$

Wang H, Shu R, Zhao Y, Zhang Q, Xu X and Zhou G (2014). Analysis of ERIC-PCR genomic polymorphism of salmonella isolates from chicken slaughter line. European Food Research and Technology, 239 (3): 543-548. DOI: https:// doi.org/ 10.1007/s00217-014-2277$\underline{\mathrm{X}}$

Wen ZG, Jiang Y, Tang J, Xie M, Yang PL and Hou SS (2016). Effect of feed consumption levels on growth performance and carcass composition during the force-feeding period in foie gras production of male mule ducks Animal, 10 (9): 1417-1422. DOI: https:// doi.org/10.1017/s175173111600032x

Wu YB, Ravindran V, Thomas DG, Birtles MJ and Hendriks WH (2004). Influence of method of whole wheat inclusion and xylanase supplementation on the performance, apparent metabolisable energy, digestive tract measurements and gut morphology of broilers. British poultry science, 45 (3): 385-394. DOI: https:// doi.org/10.1080/00071660410001730888

Xu A, Scullen OJ, Sheen S, Liu Y, Johnson JR and Sommers CH (2020). Inactivation of extraintestinal pathogenic $\mathrm{E}$. coil suspended in ground chicken meat by high pressure processing and identification of virulence factors which may affect resistance to high pressure. Food Control, $111 . \quad$ DOI:_https:// doi.org/10.1016/j.foodcont.2019.107070 
Wei et al., 2020

Yang H, Xiong X, Wang X, Tan B, Li T and and Yin Y (2016). Effects of weaning on intestinal upper villus epithelial cells of piglets. Plos One, 11 (3). DOI: https:// doi.org/10.1371/journal.pone.0150216

Yuan M, Peng L, Wu S, Li J, Song K, Chen S, Huang J, Yu J, An Q, Yi $P F$ et al. (2020). Schizandrin attenuates inflammation induced by avian pathogenic Escherichia coli in chicken type II pneumocytes. International Immunopharmacology, 81:106313-106313. DOI: https:// doi.org/10.1016/j.intimp.2020.106313
Zhang CL, Hou SS, Wang YH, Liu FZ and Xie M (2007). Feed input and excreta collection time in metabolisable energy assays for ducks. Czech Journal of Animal Science, 52 (12): 463-468. DOI: https:// doi.org/doi 10.17221/2331-cjas

Zhao X, Guo Y, Guo S and Tan J (2013). Effects of clostridium butyricum and enterococcus faecium on growth performance, lipid metabolism, and cecal microbiota of broiler chickens. Applied Microbiology and Biotechnology, 97 (14): 6477-6488. DOI: https:// doi.org/ 10.1007/s00253-013-4970-2 